\title{
Peran Bu Nyai dalam Meningkatkan Mutu Hafalan Al-Qur' an Santri Putri Pondok Pesantren Al-Hikmah Pedurungan Lor Semarang
}

\author{
Luthfiyah Natun Nawafi*, Nur Uhbiyati, Baqiyatush Sholihah
}

Universitas Islam Negeri Walisongo, Semarang, Indonesia

\begin{abstract}
ABSTRAK
Penelitian ini bertujuan untuk mendeskripsikan peran bu nyai sebagai pengasuh sekaligus pendiri pesantren dalam peningkatan mutu hafalan Al-Qur' an santri. Teknik pengumpulan data menggunakan metode observasi, wawancara, dokumentasi. Uji keabsahan data menggunakan teknik triangulasi, selanjutnya data dianalisis dengan analisis deskriptif. Hasil penelitian menunjukkan bahwa: (1) dalam peningkatan mutu hafalan Al-Qur' an, bu nyai memberikan keteladanan, pengawasan, dan pemberian motivasi, (2) hambatan yang dihadapi dalam meningkatkan mutu hafalan Al-Qur' an santri adalah kemalasan, banyaknya kegiatan santri sehingga waktu untuk menghafal dan muraja' ah berkurang, kelemahan santri dalam mengatur waktu, lemahnya ingatan, lingkungan yang kurang kondusif, kelemahan santri untuk menahan diri dari melakukan hal-hal yang kurang penting seperti terlalu banyak mengobrol dengan temannya, juga godaan terkait perasaan terhadap lawan jenis yang membuat konsentrasi untuk menghafal Al-Qur' an menjadi terganggu, (3) strategi yang digunakan bu nyai untuk meningkatkan mutu hafalan Al-Qur'an adalah dengan meminta santri untuk meningkatkan jumlah setoran hafalan, meminta santri untuk meningkatkan kualitas bacaan ayat yang disetorkan berdasarkan tajwid, makharijul-huruf, sifatul-huruf serta kelancaran dalam menghafal, mendorong santri untuk meningkatkan amaliyah penunjang mudahnya menghafal, meningkatkan kedisiplinan santri dalam menghafal melalui jadwal setoran dan muraja' ah, mendorong santri mengikuti sistem pengulangan atau takrir, mengevaluasi hafalan santri secara berkala.
\end{abstract}

Kata kunci: peran bu nyai; mutu hafalan Al-Qur' an; pesantren

\begin{abstract}
This research aims to describe the role of ibu Nyai as caregiver and proprietor of pesantren in improving the quality of AlQur' an memorization. Data collection techniques used observation methods, interviews, and documentation with trianggulation techniques, as well as analysis techniques with descriptive analysis techniques. The results showed that: (1) in improving the quality of Al-Qur' an memorization, bu Nyai provides exemplary, supervision, and motivation, (2) the obstacles faced in improving the quality of Al-Qur' an memorization are laziness, too many activities so that the time to memorize and muraja'ah becomes limited, inability to manage time, lack of memory, unconducive environment, the students' inability to refrain from doing things that are not important, such as talking or chatting too much with their friends, and related temptations. the feeling of the man who makes the students'concentration to memorize the Al-Qur' an becomes disturbed. (3) the strategy used by Bu Nyai to improve the quality of memorizing Al-Qur' an is by asking students to increase the quantity of ayat that memorized, asking students to improve the recitation quality based tajwid, makharijul-huruf, sifatul-huruf and fluency in memorizing, encourage students to improve their practice to support easy memorization, increase the discipline of students in memorizing through "setoran" and muraja'ah schedules, encourage students to follow the repetition or "takrir" system, evaluate students' memorization regularly.
\end{abstract}

Keywords: role of bu nyai; Al-Qur' an memorization quality; pesantren.

\section{PENDAHULUAN}

Sesuai dengan perkembangan zaman, lembaga pendidikan dituntut untuk memberikan yang terbaik sesuai dengan kebutuhan dan keinginan masyarakat. Salah satu lembaga pendidikan

\footnotetext{
* Corresponding Author.

Email address. nawafi.luthfiyahnatun@gmail.com (L. N. Nawafi)
} 
yang penting di Indonesia adalah pesantren. Pesantren mempunyai peran dalam pembinaan pembelajar agama Islam. Di Indonesia terdapat bermacam jenis pondok pesantren, di antaranya adalah pondok kitab (kuning) dan pondok tahfiz. Pondok kitab kuning memiliki kurikulum yang dominan berisi kajian-kajian kitab-kitab berbahasa Arab karangan para ulama' salaf atau klasik. Adapun pondok tahfiz memiliki kurikulum yang secara khusus memfasilitasi para santri untuk menghafalkan Al-Qur' an tiga puluh juz. Salah satu pondok yang memberikan fasilitas tersebut adalah Pondok Pesantren Al-Hikmah yang berlokasi di Pedurungan Lor Semarang.

Pondok Pesantren Al-Hikmah merupakan salah satu lembaga pendidikan yang mendidik santrinya untuk memperdalam ilmu agama Islam dan menghafal Al-Qur' an. Setiap pondok tahfiz tentu menginginkan mutu hafalan Al-Qur' an yang baik dari setiap santrinya, begitu juga dengan Pondok Pesantren Al-Hikmah. Banyak hal yang memengaruhi mutu hafalan para santri di AlHikmah. Sebagai contoh, santri tahfiz yang juga bersekolah umum menemukan hambatan tersendiri. Waktu mereka tersita untuk kegiatan dan tugas dari sekolah sehingga waktu untuk menghafal Al-Qur' an menjadi terbatas. Hal ini menjadi tantangan berat bagi seorang pengajar hafalan Al-Qur' an. Bu Nyai sebagai pengasuh pesantren yang hafal Al-Qur' an dan bertanggung jawab penuh atas program tahfiz memiliki peran yang penting atas mutu hafalan santri.

Dengan permasalahan-permasalahan yang ada, penulis tertarik mengkaji peran bu nyai dalam meningkatkan mutu hafalan Al-Qur' an santrinya, hambatan-hambatan dalam peningkatan mutu hafalan, serta bagaimana strategi mengatasi hambatan-hambatan. Hal ini bertujuan untuk menemukan permasalahan-permasalahan yang menghambat mutu atau kualitas hafalan Al-Qur' an para santri dan mengkaji bagaimana langkah-langkah yang diambil bu Nyai untuk mengatasi permasalahan yang ada.

\section{METODE PENELITIAN}

Penelitian yang dilaksanakan bulan Maret sampai Juni 2020 ini merupakan penelitian deskriptif kualitatif. Tempat penelitian Pondok Pesantren Al-Hikmah Pedurungan Lor-Semarang. Subjek penelitian ini adalah figur yang memiliki peran penting dalam terlaksanannya program tahfiz. Figur-figur tersebut adalah adalah pengasuh pondok pesantren; pengurus pondok pesantren (yang meliputi ketua/lurah pondok, ketua tahfiz, seksi atau divisi pendidikan), dan juga santri putri Pondok Pesantren. Objek penelitian yaitu, peran bu nyai dalam meningkatkan kualitas hafalan santri di Pondok Pesantren Al-Hikmah.

Data didapatkan dengan cara berkunjung langsung ke lokasi penelitian untuk melakukan pengamatan terhadap keadaan dan kegiatan santri tahfiz, menemui pengasuh, pengurus, dan santri putri untuk bertanya lebih detail. Pengumpulan data penelitian ini menggunakan tiga metode, yaitu: observasi, wawancara, dan dokumentasi. Wawancara dilaksanakan dengan cara berkunjung ketempat penelitian, kemudian menemui subjek penelitian setelah itu melakukan wawancara. Observasi dilakukan dengan cara menginap di tempat penelitian selama tiga hari. Dokumentasi didapatkan dengan mempelajari dokumen-dokumen Pondok Pesantren AlHikmah.

Dalam penelitian ini, analisis data menggunakan model analisis interaktifnya Miles dan Huberman. ${ }^{1}$ Tahapan dalam analisis ini meliputi data collection, data reduction, data display, dan data verification.

Mereduksi ( data reduction) berarti merangkum, memilih hal-hal yang paling penting atau paling pokok dari data yang sudah terkumpul melalui proses data collection. Data yang direduksi merupakan hasil dari wawancara dengan informan yang tersebut di atas, observasi lapangan, serta dari dokumen-dokumen pondok pesantren.

${ }^{1}$ Sugiyono, Metode Penelitian Pendidikan: Pendekatan Kuantitatif, Kualitatif, Dan R\&D(Bandung: Alfabeta, 2008). hlm. 335 
Setelah data direduksi, langkah selanjutnya adalah data display atau menyajikan data dengan tujuan untuk menyederhanakan informasi. ${ }^{2}$ Penulis menyajikan data atau informasi secara teratur dan runtut. Dengan sajian ini diharapkan peneliti akan lebih memahami berbagai hal yang terjadi dan memungkinkan untuk mengerjakan suatu analisis atau tindakan berdasarkan pemahaman yang telah dilalui.

Langkah terakhir yaitu penarikan kesimpulan. Kesimpulan ini memerlukan proses verifikasi terus-menerus selama proses berlangsung. Setelah data dikumpulkan, dipilih mana yang diperlukan dan mana yang tidak diperlukan, kemudian disusun jaringan kerja yang berhubungan dengan permasalahan penelitian. Ini dilakukan agar hasil penelitian secara kongkrit sesuai dengan keadaan yang terjadi dilapangan. Untuk menjamin validitas data, peneliti juga menggunakan triangulasi.

\section{HASIL PENELITIAN DAN PEMBAHASAN}

\section{Profil Pondok Pesantren Al-Hikmah}

Pondok pesantren Al-Hikmah pedurungan Lor Semarang terletak kurang lebih 100 meter dari jalan raya Pedurungan Penggaron, yang tepatnya Jalan Pesantren No.3 Kelurahan Pedurungan Lor RT 01 RW 05 Kecamatan Pedurungan Semarang Jawa Tengah 50192 Indonesia Telp. (024) 6716657. Pondok pesantren Al-Hikmah pedurungan Lor-Semarang dirintis M. Qodirun Nur beserta istrinya Nur Mardhiyah sekitar tahun 1985.

Kegiatan santri dimulai sejak waktu subuh hingga pukul 21.00 WIB. Sesudah salat subuh para santri membaca Al-Qur' an dengan di simak pengasuh dilanjutkan dengan persiapan ke sekolah formal disekitar ponpes. Setelah itu sore hingga malam hari para santri mengikuti pengajaran madrasah diniyah di ponpes. Beberapa kitab yang diajarkan di ponpes yakni kitab tafsir Jalalain, Ihya' Ulumudin, al-Hikam, at- Tibyan dan beberapa kitab salaf. Selain itu pelajaran yang diberikan saat madrasah yaitu nahwu, sharaf, ilmu tafsir dan beberapa ilmu untuk baca kita salaf, belum lagi pengajian kitab salaf yang digelar rutin untuk santri laju setiap jumat dan ahad pagi.

Adapun kegiatan lain selain mengaji, santri mukim di sini juga mengikuti kegiatan formal diluar pondok seperti, sekolah, kuliah, kerja, dan santri salaf yang hanya menghabiskan waktunnya didalam pondok untuk mengaji.

Pondok Pesantren Al-Hikmah Pedurungan lor memiliki banyak santri yang merupakan salah satu elemen penting dalam lembaga pesantren. Berdasarkan jumlah santri pondok pesantren Al-Hikmah mencapai 430 santri, yang terdiri dari 165 santri putra dan 265 santri putri. Adapun data terkait ngaji santri di pondok pesantrean Al-Hikmah Pedurungan Lor dapat dilihat pada tabel 1 .

Tabel 1.

\begin{tabular}{lll}
\multicolumn{3}{l}{ Data Santri Al-Hikmah Pedurungan Lor Semarang } \\
\hline No & Tingkatan & Jumlah Santri \\
\hline 1. & Bin-naz $r i$ & 190 Santri \\
2. & Bil-ghaib sambil sekolah & 25 Santri \\
3. & Bil-ghaib & 50 Santri \\
\hline Jumlah keseluruhan santri putri & 265 Santri \\
\hline $4 . \quad$ Bin-naz $r i$ & 155 Santri \\
5. $\quad$ Bil-ghaibsambil sekolah & $<10$ Santri \\
\hline Jumlah keseluruhan santri putra & 165 Santri \\
\hline Jumlah seluruh santri putra putri & 430 santri \\
\hline
\end{tabular}

${ }^{2}$ Sugiyono. hlm. 338-341 
Pondok Pesantren Al-Hikmah terdapat dua kelompok santri yaitu santri mukim dan santri kalong. Dari dua kelompok santri tersebut terdapat santri mukim yang berasal dari daerah jauh dan menetap dalam pesantren, sedangkan santri kalong berasal dari desa-desa sekitar pesantren yang tidak menetap dalam pesantren.

Jadwal setoran hafalan bagi santri bil-ghaib adalah waktu tahajud, sesudah salat zuhur, setelah subuh dan sesudah salat asar. Jadwal lengkap dapat dilihat pada tabel 2 di bawah ini:

Tabel 2.

Jadwal Kegiatan Santri Putri Pondok Pesantren Al-Hikmah Pedurungan Lor-Semarang

\begin{tabular}{|c|c|}
\hline Waktu & Kegiatan \\
\hline $03.00-04.00$ & Setoran Al-Qur' an (bil-ghaib) \\
\hline $04.30-05.00$ & Jama'ah salat subuh \\
\hline 05.00-selesai & Setoran/darusan Al-Qur' an (bin-nazri dan bil-ghaib) \\
\hline $07.30-10.30$ & Muraja' ah 1 juz (berpasangan) \\
\hline $10.30-12.30$ & Istirahat \\
\hline 13.00-selesai & Jama' ah salat dhuhur dilanjut setoran (bil-ghoib) \\
\hline $14.00-16.00$ & Istirahat \\
\hline 16.00-selesai & Jama' ah salat asar dilanjut setoran (bin-nazri dan bil-ghaib) \\
\hline 18.00-selesai & Jama'ah salat maghrib \\
\hline $18.30-19.00$ & Pengajian kitab kuning \\
\hline 19.00-selesai & Jama'ah salat isya' \\
\hline 19.30-selesai & Muraja' ah $1 / 2$ juz (berpasangan) \\
\hline
\end{tabular}

\section{Peran Bu Nyai dalam Meningkatkan Mutu Hafalan Al-Qur' an Santri}

Agar bisa dikatakan bermutu baik, hafalan Al-Qur' an harus sesuai kaidah ilmu tajwid bacaannya, tartil, serta lancar. Ibnu Jauzi berkata dalam syairnya (At-Tayyibah fi al-Qira' ah alAsyr): " menggunakan tajwid adalah ketentuan yang lazim, barang siapa yang mengabaikan maka dia berdosa". Makna tajwid adalah memperhatikan hukum-hukum yang ada dalam kitabkitab tajwid, seperti idgham, ikhfa', gunah dan mad serta memperhatikan makhorijul hurufnya. ${ }^{3}$ Bacaan Al-Qur' an yang bermutu harus selamat dari kekeliruan pelafalan baik kekeliruan yang merusak makna yang disebut lahn jally maupun kesalahan-kesalahan halus yang masuk kategori lahn khafy. ${ }^{4}$

Tartil adalah baik sebutan hurufnya, baik mengucapkan kalimatnya, baik waqof ibtida' nya, dan baik muraja' ahnya. ${ }^{5}$ Allah Swt berfirman dalam Al-Qur' an surat al-Muzammil ayat 4 sebagai berikut: "atau lebih dari seperdua itu. dan bacalah Al Quran itu dengan perlahanlahan."(Q.S. al-Muzamil/73: 4)

Kelancaran membaca adalah hal yang paling utama dalam menghafal Al-Qur' an. Lancar di sinitidak berarti tanpa lupa, karena manusia tidak luput dari lupa, apalagi menghafal Al-Qur' an yang begitu tebal kitabnya. Kelancaran membaca dapat memberikan semangat tersendiri bagi penghafal Al-Qur'an untuk selalu mentakrir hafalanya, sehingga hafalan Al-Qur' an selalu terjaga.

Bu Nyai memiliki peran sebagai pemimpin puncak mendampingi pak kiai di pesantren. Di Al-Hikmah, program tahfiz Al-Qur'an santri putri secara penuh dipimpin oleh bu nyai. Kepemimpinan bu nyai meliputi proses memengaruhi dalam menentukan tujuan organisasi, memotivasi anggota untuk mencapai tujuan, dan mempengaruhi untuk memperbaiki kelompok. Kepemimpinan di sini merupakan faktor penting yang berpengaruh langsung terhadap berhasil atau tidaknya suatu organisasi. Kepemimpinan (leadership) merupakan intisari manajemen. Kepemimpinan dapat diartikan sebagai:

\footnotetext{
${ }^{3}$ Hasan bin Ahmad bin Hasan Hamam, Menghafal Al-Qur' ãn Itu Mudah (Jakarta: Pustaka At-Tazkia, 2008). hlm. 23-24

${ }^{4}$ Baqiyatush Sholihah, "Evaluasi Dan Supervisi Program Pembelajaran Al-Qur' an Di Sekolah Dasar Islam Bilingual AnNissa Semarang," Tarbawi: Jurnal Pendidikan Islam 15, no. 1 (2018). hlm. 59

${ }^{5}$ Muhaimin Zenha, Pedoman Pembinaan Tahfidzul Qur' an (Jakarta: Proyek Penerangan, 1983). hlm. 96
} 
a. Seni mempengaruhi sikap dan mengarahkan pendapat orang dengan dasar kepatuhan, kepercayaan, hormat dan kerjasama yang bersemangat dalam mencapai tujuan bersama.

b. Orang yang menerapkan prinsip dan teknik yang memastikan motivasi, disiplin dan produktivitas dalam mencapai tujuan bersama.

c. Kekuasaan yang melibatkan hubungan dengan orang lain.

d. Pemberi kemudahan yang membantu melancarkan pencapaian tujuan. ${ }^{6}$

Seorang pemimpin setidaknya mempunyai tiga ciri, yakni: memiliki kemampuan penglihatan sosial (social perception), kemampuan berfikir abstrak (ability in abstract thinking), dan memeiliki keseimbangan emosional (emotional stability). ${ }^{7}$

Leader adalah orangnya, sedangkan leadership ialah gaya atau style seorang manajer untuk mengarahkan, mengkoordinasi, dan membina para bawahanya agar mau bekerjasama dan bekerja produktif mencapai tujuan organisasi. Gaya kepemimpinan berhubungan dengan pola atau model yang dimiliki oleh seseorang sehingga terbentuklah suatu perilaku yang rutin. Gaya merupakan model seseorang yang selalu nampak dan menjadi ciri khas orang tersebut. Pasolong (2007:37) mengemukakan bahwa gaya kepemimpinan adalah suatu cara yang digunakan oleh seorang pemimpin dalam mempengaruhi, mengarahkan, mendorong, dan mengendalikan bawahannya dalam rangka pencapaian tujuan organisasi secara efisien dan efektif.

Sebagai pemimpin pesantren mendampingi pak yai, bu nyai berperan sebagai pendidik. Tugasnya tidak hanya mengajar, tetapi juga membimbing dan mengarahkan santri-santrinya agar dapat berkembang dengan baik. Bu nyai memberikan contoh beragama sesuai dengan syariat Islam berdasarkan ajaran Rasulullah sebagaimana mendidik santri ngaji serta sopan santun terhadap guru. Bu nyai di sini mempunyai peranan penting dalam mempengaruhi, mendorong (memotivasi), mengarahkan serta menggerakkan santrinya untuk mendalami ilmu agama dan membina santrinya agar mau bekerjasama dan produktif agar tercapai tujuan bersama. Sebagai figur yang mengelola prgram tahfiz, bu nyai bertanggungjawab atas hafalan santri. Baik buruknya mutu hafalan santri tergantung pada kemampuan bu nyai dalam mengelola atau memanageri.

Berdasarkan analisis peneliti, peran kepemimpinan bu nyai dalam meningkatkan mutu hafalan santri di Pondok Pesantren Al-Hikmah Pedurungan Lor Semarang adalah sebagai berikut:

a. Keteladanan

$\mathrm{Bu}$ nyai sebagai pemimpin memiliki pengaruh besar yang dipercaya oleh sebagaian kalangan publik. bu nyai juga dipandang sebagai tokoh yang luar biasa di dalam perkembangan pada aspek kelembagaan. Bu nyai Nur Mardhiyah sebagai pengasuh pondok pesantren Al-Hikmah berperan penting memberikan teladan bagi kehidupan santri dalam meningkatkan mutu hafalan santri. Bu nyai selalu memberikan keteladanan dalam peningkatan mutu hafalan santri. Bu nyai memberikan teladan melalui kehidupan sehari-harinya maupun kebijakan yang telah ditetapkan oleh pengasuh.

\section{b. Pengawasan}

Bu nyai sangat aktif melakukan pengawasan baik dengan cara pengawasan secara langsung maupun tidak langsung. Pengawasan dilakukan dengan memantau kegiatan-kegiatan yang dilaksanakan santri. Kinerja pengurus terkait dengan program tahfiz baik kegiatan harian, kegiatan mingguan, dan kegiatan bulanan diawasi oleh bu nyai. Ketika dalam pengawasan pengasuh menemukan salah satu kesalahan maka bu nyai bertugas menegur dan langsung memperbaiki kesalahan yang terjadi yaitu dengan cara musyawaroh bersama maupun dengan pihak pengurus. Gaya kepemimpinan bu nyai ini adalah partisipatif.

${ }^{6}$ Al Fadjar Ansori dan Meithiana Indrasari, Manajemen Sumber Daya Manusia(Sidoarjo: Indomedia Pustaka, 2018). hlm.

\footnotetext{
${ }^{7}$ Kompri, Manajemen Dan Kepemimpinan Pondok Pesantren(Prenadamedia Group, 2018). hlm.182
} 


\section{c. Pembimbingan}

Bu nyai memberikan arahan untuk membimbing santrinya agar hafalan tetap terjaga serta mencapai target hafalan yang diinginkan. Selain membimbimbing agar santri mampu mencapai target hafalan secara kuantitas, bu nyai juga memberikan bimbingan terkait kualitas bacaan tajwid, makharijul huuf, serta kelancaran dalam menghafal.

\section{d. Pemberian motivasi}

Peran kepemimpinan bu nyai dalam memberikan motivasi terkait dengan peningkatan mutu hafalan santri sangat erat kaitannya dengan dorongan yang diberikan untuk santrinya agar mutu yang diinginkan tercapai dengan baik. Bu nyai sebagai motivator dapat memberikan dorongan agar bersemangat serta menumbuhkan rasa sadar diri terhadap kesalahan yang telah diperbuatnya. Pengasuh memberikan nasehat atau memotivasi santri dengan cara seluruh santri dikumpulkan menjadi saatu kemudian kiai memberikan nasehat berdasarkan kebutuhan santri.

\section{Hambatan Menghafal Al-Qur' an}

Hambatan dalam menghafal Al-Qur' an yang dihadapi oleh santri antara lain berhubungan dengan ayat yang sulit, terlupanya ayat yang sudah dihafal, gangguan lingkungan, keterbatasan waktu, kemalasan, gangguan dari lawan jenis, dll.

Di Al-Qur' an terdapat banyak sekali ayat-ayat yang mirip sehingga santri sering terbalikbalik dalam menghafalkannya. Santri juga menghadapi problem ayat-ayat yang sudah dihafal terlupa meski bukan ayat-ayat mirip. Kadang-kadang ayat-ayat ketika dihafal diri sendiri sudah lancar, namun ketika disimak teman atau bu nyai jadi terlupa. Cara mengatasinya ialah hendaknya sebelum memperdengarkan hafalan kepada bu nyai, terlebih dahulu hafalan yang sudah dihafal dengan lancar harus diulangi lagi seperti hafalan yang baru atau minta bantuan teman untuk menyimak.

Hambatan lain adalah gangguan lingkungan karena suasana yang ramai dan tidak adanya tempat khusus untuk santri tahfiz. Baik buruknya keadaan lingkungan sangat mempengaruhi konsentrasi dalam menghafalkan Al-Qur' an. Muhaimin Zen menjelaskan tentang cara mengatasi lingkungan-lingkungan yang kurang mendukung dalam proses menghafal al-Quran diantaranya dengan mencari tempat yang sunyi. Beberapa jenis suara orang yang berbicara dapat mengganggu konsentrasi. Selain kondisi lingkungan yang ramai, santri kadang juga tergoda untuk mengobrol dengan temannya sehingga waktu yang seharusnya untuk menambah hafalan atau muraja' ah menjadi terbuang.

Hambatan lain yang dihadapai santri adalah keterbatasan waktu yang menyebabkan waktu untuk menghafal dan muraja' ah terasa kurang. Selain mengaji, santri juga memiliki tugas piket masak yang dilaksanakan dua kali per minggu. Sebagian santri tahfiz merasa keberatan terhadap piket masak karena bagi mereka tugas itu cukup menyita waktu.

Santri kadang juga tidak sabar, malas dan putus asa, sedangkan menghafal Al-Qur' an diperlukan kerja keras dan kesabaran yang terus-menerus. ${ }^{8}$ Terkadang waktu yang kosong terbuang sia-sia, yang seharusnya waktu luang itu digunakanakan untuk menambah hafalan dan muraja'ah, namun rasa malas itu tiba-tiba muncul. Rasa malas itu sedikit demi sedikit telah mengikis hafalan yang sudah didapat. Terkadang waktu luang seperti ini sering kali disepelekan oleh santri, tanpa disadari bahwa hafalan mereka hilang.

Kurang teliti dalam memperhatikan tulisan ayat serta harakat saat menghafalkan sehingga hafalan keliru juga menjadi hambatan menghafal. Hambatan lain adalah godaan dari lawan jenis. Sebagian santri menghadapi godaan dari lawan jenis yang menyebabkan mereka sulit untuk berkonsentrasi karena pikiran mereka terpecah untuk memikirkan lawan jenis.

${ }^{8}$ Abdul Aziz Abdul Rauf, Kiat Sukses Menghafal Al-Qur' ãn : Sarat Dengan Penanaman Motivasi,Penjelasan Teknis Dan Pemecahan Masalah (Jakarta: Dzilal Press, 1996). hlm. 76 


\section{Strategi untuk Meningkatkan Mutu Hafalan Al-Qur' an Santri Putri di Pondok Pesantren Al-Hikmah Pedurungan Lor Semarang}

Berdasarkan analisis penelitian, peran bu nyai dalam meningkatkan mutu hafalan AlQur'an Peningkatan mutu dapat diwujudkan melalui manajemen mutu terpadu. Dalam penjaminan mutu tersebut dilakukan secara menyeluruh, sehingga tidak ada unsur yang terbaikan dalam perbaikan mutunya selama terkait dengan program tahfiznya.

Secara singkat strategi yang yang diambil bu nyai dalam meningkatkan mutu hafalan santri adalah sebagai berikut.

a. Bu nyai meminta santri untuk meningkatkan jumlah setoran ayat.

Para santri yang mengikuti program tahfiz biasanya memiliki target. Bu nyai memperhatikan hal ini sehingga tahu mana santri yang perlu diminta untuk meningkatkan jumlah hafalan dan mana yang sudah mampu jalan sendiri tanpa diminta. Untuk meningkatkan hafalan, santri perlu tahu kapan waktu yang tepat untuk menghafal sehingga proses menghafal menjadi efektif dan efisien. Waktu khusus saat yang baik untuk menghafal, diantaranya: waktu yang biasanya adalah siang dan malam karenan tercakup dalam lima waktu salat. Waktu mesti diatur sesuai dengan kesibukan. Kemudian adanya target yang sesuai dengan kemampuan, yakni berapa lama waktu yang dibutuhkan untuk menhghafal sampai khatam. Dengan adanya target tersebut, seorang penghafal Al-Qur' an dapat memperkirakan seberapa banyak hafalan yang harus disetorkan setiap harinya agar khatam sesuai target. ${ }^{9}$

b. Bu nyai meminta santri untuk meningkatkan kualitas bacaan ayat yang disetorkan berdasarkan tajwid, makhorijul huruf, serta kelancaran dalam menghafal.

Sebelum memulai hafalan, seorang penghafal Al-Qur'an harus membetulkan dan melancarkan bacaanny. ${ }^{10}$ Dalam hal ini hendaknya seorang penghafal terlebih dahulu melakukkan hal sebagai berikut: meluruskan bacaannya sesuai dengan kaidah tajwid, memperlancar bacaannya, serta melatih lisan dan bibir untuk senantiasa membaca ayat-ayat AlQur' an agar bacaannya terbiasa dengan fasih berdasarkan tajwid. Bu nyai sangat memperhatikan hal ini ketika santri memulai menghafal, karena kelancaran serta ketepatan dalam melafalkan adalah hal sangat penting.

\section{c. Mendorong santri untuk meningkatkan amaliyah penunjang mudahnya menghafal}

Menurut Sugianto sebelum memulai untuk menghafal Al-Qur' an seorang penghafal hendaknya memenuhi syarat yang berhubungan dengan naluri insaniyahnya. ${ }^{11}$ Kehormatan penghafal Al-Qur'an bukan terletak pada hafalannya, melainkan kualitas hidup dan peradabannya.

d. Meningkatkan kedisiplinan santri dalam menghafal.

Untuk mendisiplinkan santri, bu nyai dengan pengurus menyusun jadwal kegiatan harian, mingguan, dan bulanan sebagaimana berikut:

Kegiatan harian yang terdiri atas kegiatan setoran dan muraja' ah. Setoran waktu tahajud dan sesudah salat dhuhur, atau setoran waktu subuh dan sesudah salat asar. Setoran Bilghoib menyesuaikan jadwal ibu nyai. Kegiatan muraja' ah dibagi menjadi dalam beberapa jadwal yaitu:

${ }^{9}$ Makhyardin, Rahasia Nikmatnya Menghafal Al-Qur' ãn(Jakarta: PT. Mizan Publika, 2016). hlm. 64

${ }^{10}$ Tutik Khoirunnisa, "Penerapan Metode Wahdah Dalam Meningkatkan Hafalan Al-Qur' ãn Santri" (IAIN Salatiga, 2016).

\footnotetext{
${ }^{11}$ Sugianto dan Ilham Agus., Kiat Praktis Menghafal Al-Qur' ãn(Bandung: Mujahid Pres, 1994). hlm. 58
} 
muraja'ah yang dilakukan setiap hari setalah setoran Al- Qur'ãn secara berpasangan; muraja' ah setiap pagi jam 07.30-10.30 satu juz secara berpasangan; muraja'ah setiap sore 16.00-selesai setengah juz berpasangan; muraja' ah malam ba' da isya' setengah juz dilakukan berpasangan (setiap malam jumat, malam sabtu, malam minggu, dan malam senin); muraja'ah pukul 08.00-10.30 setiap hari (senin, rabu, kamis, sabtu) dilakukan berpasangan satu juz, tempat masjid; setiap hari libur (Selasa dan Jumat). Muraja' ah hari Selasa dilaksanakan setiap jam 07.00selesai dengan model tartilan lima juz yang dilakukan secara berkelompok lima orang berdasarkan juz yang didapat. Dalam kelompok ini tiap santri membacakan hafalan mereka bergantian per halaman. Adapun muraja' ah hari Selasa dilasksanakan setiap ba' da dzuhur satu juz secara kelompok menyesuaikan (dilakukan bergantian per-ayat). Untuk hari Jum'at dilaksanakan ba'da subuh dengan model tartilan tiga juz secara kelompok (lima orang) bedasarkan juz yang sudah dihafalkan. Dalam kelompok ini santri membaca bergantian per halaman.

Kegiatan mingguannya adalah sima' an ahad pagi tiga juz, yang dilakukan bersama warga sekitar dan sima' an Selasa pagi, yang dilakukan bersama alumni dari kader tua-kader muda. Adapun kegiatan bulanannya berupa kegiatan sima' an/tartilan 30 juz "sewelasan" (tanggal 11 Hijriyah) dengan cara membaca per halaman secara maraton.

e. Mendorong santri untuk mengikuti sistem pengulangan

Untuk mencapai mutu hafalan yang baik tidak lepas dari cara untuk memelihara hafalan Al-Qur' an. Adapun untuk memelihara hafalan Al-Qur' an atau meningkatkan hafalan Al-Qur' an antara lain dengan cara pengulangan/muraja' ah/tikror|takrir. Takrir ini dapat dilakukan dengan cara-cara pada tabel 3.

Tabel 3.

Model Takrir Santri Putri Pondok Pesantren Al-Hikmah

\begin{tabular}{|c|c|c|}
\hline No & Metode & Rincian \\
\hline 1 & Takrir sendiri & $\begin{array}{l}\text { Seseorang yang menghafalkan Al-Qur' an harus memanfaatkan waktu untuk takrir dan untuk } \\
\text { menambah hafalan. Hafalan yang baru harus selalu ditakrir minimal setiap hari dua kali dalam } \\
\text { jangka waktu satu minggu. Sedangkan hafalan yang lama harus ditakrir setiap hari atau dua hari } \\
\text { sekali, artinya, semakin banyak hafalan harus semakin banyak pula waktu yang dialokasikan untuk } \\
\text { takrir. }\end{array}$ \\
\hline 2 & Takrir dalam salat & $\begin{array}{l}\text { Seorang penghafal Al-Qur' an hendaknya bisa memanfaatkan hafalannya sebagai bacaan dalam } \\
\text { salat. Baik sebagai imam atau untuk salat sendiri. Selain untuk menambah keutamaan salat, cara } \\
\text { demikian juga akan menambah kemantapan hafalan Al-Qur' an }\end{array}$ \\
\hline 3 & Takrir bersama & $\begin{array}{l}\text { Seorang penghafal Al-Qur' an perlu melakukan takrir bersama dengan dua teman atau lebih. Dalam } \\
\text { takrir ini setiap orang membaca materi takrir yang ditetapkan secara bergantian, dan ketika seorang } \\
\text { membaca, maka yang lain mendengarkan }\end{array}$ \\
\hline 4 & $\begin{array}{l}\text { Takrir di hadapan } \\
\text { guru }\end{array}$ & $\begin{array}{l}\text { Seorang penghafal Al-Qur' an harus selalu menghadap guru untuk takrir hafalan yang sudah } \\
\text { diajukan. Materi takrir yang dibaca harus lebih banyak dari materi hafalan baru, yaitu satu banding } \\
\text { sepuluh, artinya apabila seorang penghafal sanggup mengajukan hafalan baru setiap hari dua } \\
\text { halaman, maka harus diimbangi dengan takrir dua puluh halaman (satu juz) setiap hari. }\end{array}$ \\
\hline
\end{tabular}

\section{f. Mengevaluasi hafalan santri}

Evalusi ini dilaukan dengan cara santri menyetorkan hafalannya kepada bu nyai, dan bu nyai mengoreksi setiap kesalahan dalam setoran Al-Qur' an dari segi, makhorijul huruf, sifatul huruf, hukum-hukum tajdwid lainnya serta kelancaran dalam mengahafal.

Evaluasi hafalan dilaksanakan dengan beberapa tahap, yakni: evaluasi seperempat juz AlQur' an setelah setoran $5 \mathrm{kaca} /$ halaman, wajib sema' an $1 / 4$ juz berpasangan dengan temannya, tempat pelaksanaan dilakukan disebelah kanan ibu nyai saat ngaji; evaluasi setengah juz AlQur' an setelah setoran 10 kaca/halaman; evaluasi satu juz Al-Qur' an satu juz, setelah setoran 20 kaca/halaman sema' an dilakukan berpasangan, tempat diaula masjid putra; evaluasi awal juz 
sampai akhir juz yang dihafal. Setiap santri yang sudah hafal 15 juz keatas, kegiatan sima' an dilakukan bersama orang tua dan juga seluruh santri tahfiz untuk menyaksikannya di aula putra.

Semua kebijakan dibuat oleh bu nyai, dan diberikan kepada pengurus untuk mengolah kembali kebijakan yang telah ditetapkan. Pengurus memusyawarahkan kebijakan berdasarkan kondisi santri, yang bertujuan agar tidak memberatkan keduanya.

\section{SIMPULAN}

Berdasarkan dari hasil penelitian tentang "Peran Bu nyai dalam Meningkatkan Mutu Hafalan Santri Putri di Pondok Pesantren Al-Hikmah" peneliti dapat mengambil kesimpulan sebagai berikut.

1. Peran kepemimpinan bu nyai Nur Mardliyah dalam meningatkan mutu hafalan santri sebagai berikut: a) memberikan keteladanan melalui kehidupan sehari-harinya maupun kebijakan yang telah ditetapkan; b) memberikan pengawasan baik secara langsung maupun tidak langsung. kegiatan yang sudah terlaksana di antaranya: kegiatan harian, kegiatan mingguan, dan kegiatan bulanan. Dengan terstrukturnya kegiatan dengan baik, sangat mudah bagi pengasuh untuk melakukan pengawasan; c) memberikan bimbingan kepada santri. Bu nyai sebagai pembimbing santrinya memberikan arahan kepada santrinya agar hafalan tetap terjaga serta tercapainya target yang bagus; d) memberikan motivasi kepada santri untuk meningkatkan mutu hafalan santri. Bu nyai memberikan motivasi berupa dorongan, ajakan, serta mempengaruhi dan menggerakkan seluruh komponen yang ada di pondok pesantren agar santri belajar dengan sungguh-sungguh dalam menghafal Al-Qur' an.

2. hambatan yang dihadapi dalam meningkatkan mutu hafalan Al-Qur'an santri adalah kemalasan, banyaknya kegiatan yang harus diiukuti santri sehingga waktu untuk menghafal dan muraja'ah menjadi terasa terbatas bagi santri, kekurangmampuan santri dalam mengatur waktu, kurang kuatnya ingatan, lingkungan yang kurang kondusif, kekurangmampuan santri untuk menahan diri melakukan hal-hal yang kurang penting seperti terlalu banyak mengobrol dengan temannya, juga godaan terkait perasaan terhadap lawan jenis yang membuat konsentrasi santri untuk menghafal Al-Qur' an menjadi terganggu.

3. strategi yang digunakan bu nyai untuk meningkatkan mutu hafalan Al-Qur' an adalah dengan meminta santri untuk meningkatkan jumlah setoran hafalan, meminta santri untuk meningkatkan kualitas bacaan ayat yang disetorkan berdasarkan tajwid, makharijul-huruf, sifatul-huruf serta kelancaran dalam menghafal, endorong santri untuk meningkatkan amaliyah penunjang mudahnya menghafal, meningkatkan kedisiplinan santri dalam menghafal melalui jadwal setoran dan muraja' ah, endorong santri untuk mengikuti sistem pengulangan/takrir, mengevaluasi hafalan santri secara berkala untuk setiap santri.

\section{DAFTAR PUSTAKA}

Agus., Sugianto dan Ilham. Kiat Praktis Menghafal Al-Qur' an. Bandung: Mujahid Pres, 1994.

Fadjar Ansori dan Meithiana Indrasari, Al. Manajemen Sumber Daya Manusia. Sidoarjo: Indomedia Pustaka, 2018.

Hamam, Hasan bin Ahmad bin Hasan. Menghafal Al-Qur' an Itu Mudah. Jakarta: Pustaka AtTazkia, 2008.

Khoirunnisa, Tutik. "Penerapan Metode Wahdah Dalam Meningkatkan Hafalan Al-Qur'an Santri." IAIN Salatiga, 2016.

Kompri. Manajemen Dan Kepemimpinan Pondok Pesantren. Prenadamedia Group, 2018. Makhyardin. Rahasia Nikmatnya Menghafal Al-Qur' an. Jakarta: PT. Mizan Publika, 2016. 
Rauf, Abdul Aziz Abdul. Kiat Sukses Menghafal Al-Qur'an : Sarat Dengan Penanaman Motivasi,Penjelasan Teknis Dan Pemecahan Masalah. Jakarta: Dzilal Press, 1996.

Sholihah, Baqiyatush. "Evaluasi Dan Supervisi Program Pembelajaran Al-Qur' an Di Sekolah Dasar Islam Bilingual An-Nissa Semarang." Tarbawi: Jurnal Pendidikan Islam 15, no. 1 (2018).

Sugiyono. Metode Penelitian Pendidikan: Pendekatan Kuantitatif, Kualitatif, Dan R\&D. Bandung: Alfabeta, 2008.

Zenha, Muhaimin. Pedoman Pembinaan Tahfidzul Al-Qur' an. Jakarta: Proyek Penerangan, 1983. 